\title{
Design Construction and Performance Evaluation of Solar Still for Rural Dwellers
}

\section{Safyanu Bashir Danjuma ${ }^{1}$, Aliyu Mohammed Lawal ${ }^{1}$, Ibrahim Shuaibu Muhammad ${ }^{1}$, Ojonimi Yusuf Usman ${ }^{2}$}

\author{
${ }^{1}$ Abubakar Tatari Ali Polytechnic \\ P. M. B 0094, Bauchi, Nigeria \\ ${ }^{2}$ The Federal Polytechnic Idah \\ P. M. B 1037, Idah, Nigeria
}

DOI: $10.22178 /$ pos.39-1

LCC Subject Category:

TA166-167

Received 01.08.2018

Accepted 15.09.2018

Published online 31.10.2018

Corresponding Author:

Safyanu Bashir Danjuma

bashir.12393@yahoo.com

(C) 2018 The Authors. This article

is licensed under a Creative Commons

Attribution 4.0 License @)

\begin{abstract}
This paper is aimed at designing, constructing and performance evaluation of a solar still. The solar still is design and constructed with locally source materials for rural dwellers. The still absorber plate is constructed with $2 \mathrm{~mm}$ galvanised plate painted black with an area of $2 \mathrm{~m}^{2}$ to absorb solar radiation effectively. The side wall and the base is constructed with concrete. Sawdust and felt is used between the retaining wall and base to resist heat transfer from the system to the surrounding vice-versa. The top cover of the still is constructed with transparent glass pane of $4 \mathrm{~mm}$ housed in an aluminium frame. The catch basin that collects the condensate is constructed with PVC pipe channel of $50 \mathrm{~mm}$. The performance of the still was evaluated with; Overall yield (sum of daily yield and over-night yield) at a different water depth of $(20,40$, $60 \mathrm{~mm}),\left(5127 \mathrm{ml} / \mathrm{m} 2 / \mathrm{hr}, 4558 \mathrm{ml} / \mathrm{m}^{2} / \mathrm{hr}\right.$, and $\left.3852 \mathrm{ml} / \mathrm{m}^{2} / \mathrm{hr}\right)$. The efficiency of the system at different water depth $(20,40,60 \mathrm{~mm}) 51.27 \%$, $45.58 \%$, and $38.52 \%$. The water analysis before and after distillation was certified safe and portable for human consumption.
\end{abstract}

Keywords: solar still; construction; performance evaluation; design; efficiency.

\section{INTRODUCTION}

Water is essential for human survival with the compliment of food and air. Most of the water in the world is contaminated and not safe for human consumption there for; there is a need for water purification [8]. The Earth has an insufficient source of fresh water that is in the liquid state, and most are polluted by harmful bacteria and toxic chemicals [10]. Unfortunately, typical purification systems are easily damaged or compromised by natural disasters or another form of destruction [2]. All this attributed to the problem to make such diseases and toxic chemicals to be prevalent in the brackish water [11]. A solution to these problems is inevitable and need not to overemphasis. The answer is a technology that is not only capable of removing a vast variety of contaminants in just one step but is straightfor- ward, cost-effective, and environmentally friendly, that is the use of solar energy [1].

Various types of conventional solar still; Greenhouse solar still generally emulates the natural hydrologic cycle to produce the distilled water [9, 7]. Horizontal concentric tube solar still uses the air as the working medium [4]. Cylindrical parabolic type solar still used a parabolic reflector [3].

This paper aims to design, construct and performance evaluation of a solar still for rural dwellers to improve the productivity of the distilled water.

A solar distillation device contains three primary mechanisms: a basin which contained the contaminated water; a glass pane that traps the condensed water, and a catch basin which collect the distilled water [6]. 
The solar still design is made of a wooden box as the outside cover with a dimension of $2200 \mathrm{~mm}$ by $1200 \mathrm{~mm}$ at the bottom. The side wall is slanted at an angle of $10.4^{\circ}$ with a height of 380 $\mathrm{mm}$ at the rear and height of $200 \mathrm{~mm}$ at the front of the solar still. The inside of the solar still is made of Galvanised iron sheet shaped to the wooden box with the dimension of $2000 \mathrm{~mm}$ by
$1000 \mathrm{~mm}$ at the base and height of 380 at the rear and $200 \mathrm{~mm}$ at the front and painted black to facilitate heat from the solar radiation. The top is covered with a transparent glass, slant to the inclined angle. Saline or brackish water is poured into the still to fill to a predetermined level and then exposed to the solar radiation (Figure 1).

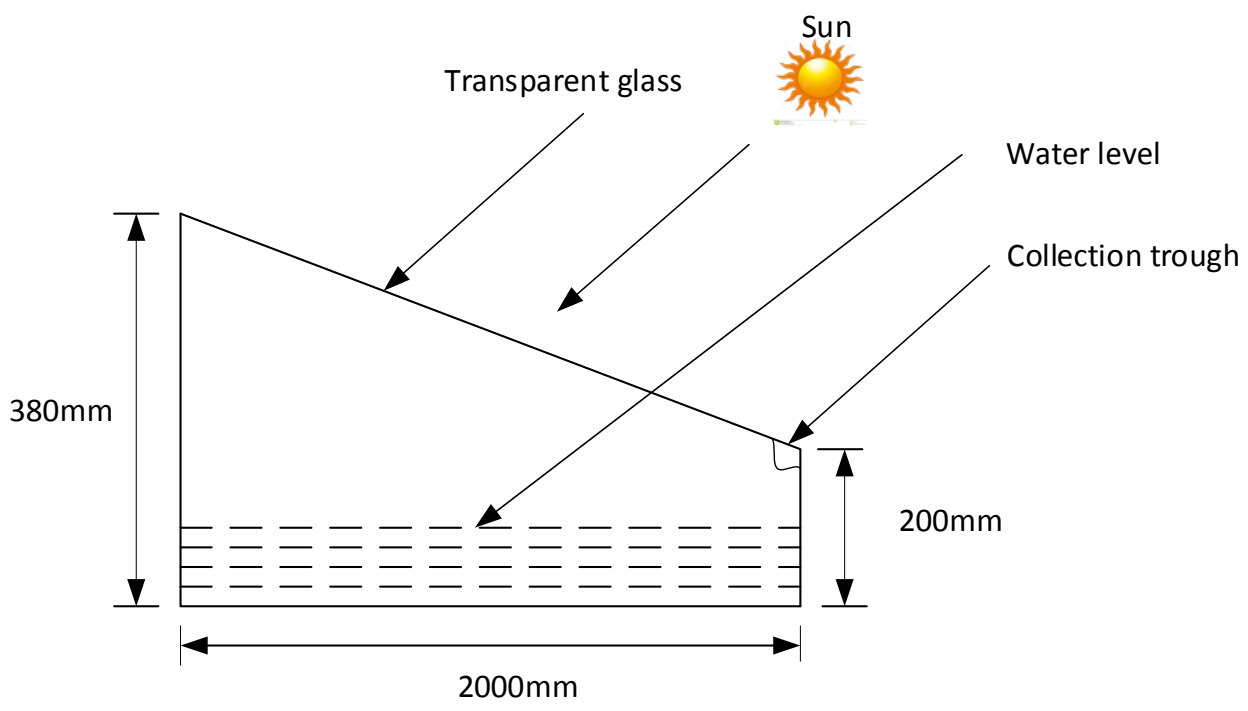

Figure 1 - A typical solar still

The glass cover permits solar radiation to get into the still, which is absorbed predominantly by the black base. Consequently, the water gets heated up and hence there is an increase of hot moist air that occurred between the water surface and the glass bottom level. The bottom also radiates energy in the infrared region which is mainly absorbed by water in the basin. Thus, the glass cover traps the solar energy inside the still. It also reduces the convective heat losses. The glass cover is usually sloped to enable the water vapour which condenses on the interior surface to trickle into a collecting trough/ catch basin.

The solar still pilot plant consists of asymmetrical solar stills arrange in two rows, and each of the rows is made of six solar still, which comprises of a total of twelve solar still. The dimension of $2 \mathrm{~m}^{2}$, with an inclination of $10.4^{\circ}$ (base on the latitude of Bauchi), the orientation of north to south and the same for the entire twelve solar still.

The still consist of three essential components: (a) Basin made of galvanised iron and painted black, in which the contaminated water is confined; (b) A transparent glass pane $4 \mathrm{~mm}$ thickness which covers the still and vapour condenses from the feed water;

(c) A catch basin, which collected the distilled water into the storage tank $(500 \mathrm{~L})$.

Each of the still has an inlet where brackish or contaminated water is feed into the still from the stream via overhead tank $(2000 \mathrm{~L})$, and drain where deposited wastewater from the still is flush after prolonged use. And a storage tank $(2000 \mathrm{~L})$ were distilled water is pumped from the $500 \mathrm{~L}$ tank.

\section{Design and Construction of Different Components of the Solar Still}

Design Assumptions. 1. Inclination angle $-10.4^{\circ}$. 2. Orientation - north to south. 3. Ambient and Operating Conditions - same for the entire twelve still. 4. Glass temperature - uniform within the whole glass. 5 . No leakage in the still basin.

Design and Construction of Still Basin (Absorber Plate). The component where the contaminated water is placed and absorb solar radiation. The 
material most have high absorptivity or very less reflectivity and very less transitivity. These are the criteria's for selecting the basin materials. Some of the materials that can be used are as follows: 1 . Leather sheet, 2 . Ge silicon, 3. Mild steel plate, 4. RPF (reinforced plastic) 5. G. I. (galvanised iron).
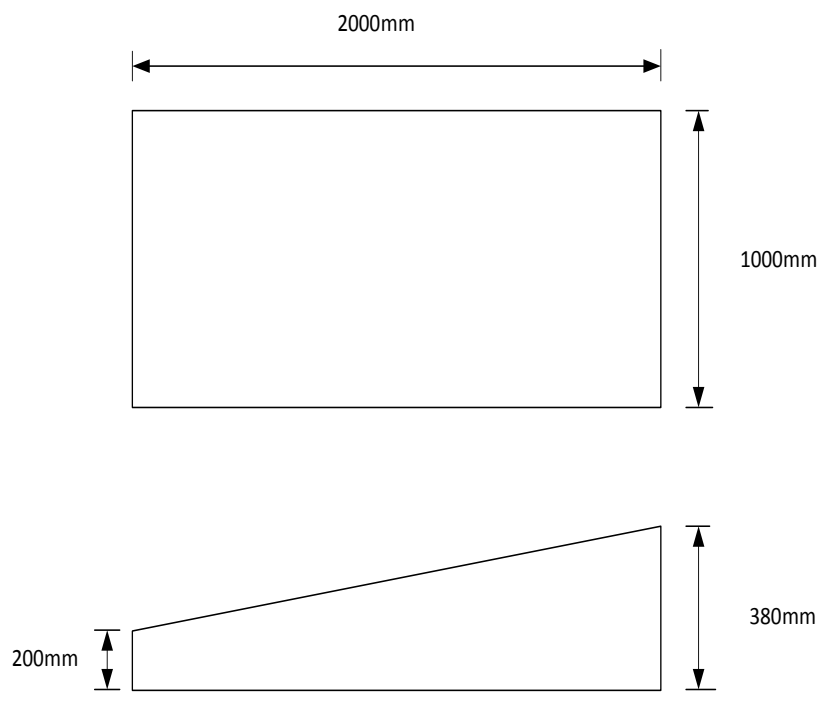

The still basin: galvanised iron sheet $(2 \mathrm{~mm})$ was found to be the best material for the design. The galvanised iron sheet is used in the construction and is painted black to effectively absorb solar radiation and convert it to heat and transfer the heat to the water (Figure 2)..

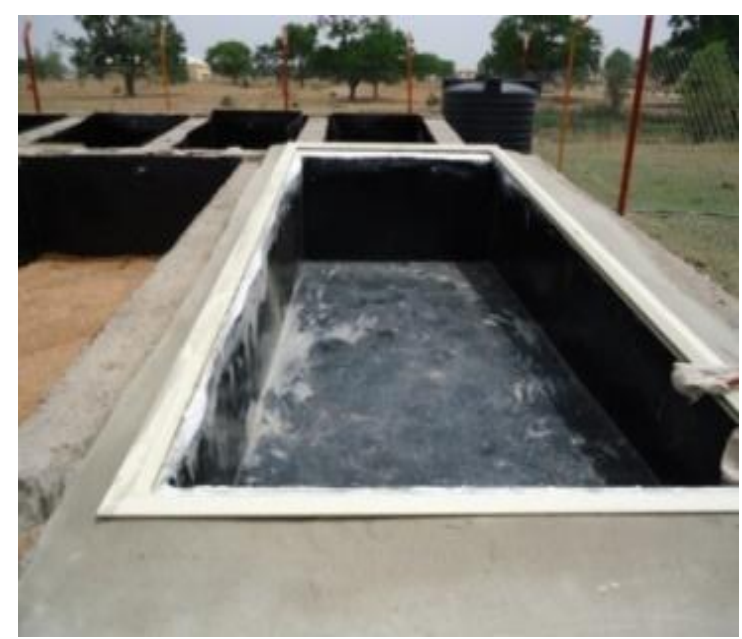

Figure 2 - Still basin: Design and pictorial views of the still basin

Design and Construction of Side Wall (Retaining Wall). The side wall provides support to the solar still and also, prevents heat transfer from the still to the surrounding. The materials that are most suitable for a retaining wall are; wood, Concrete, Thermocol, and RPF (reinforced plastic).
The concrete wall was used in the construction to serve as a retaining wall and to provide rigidity and durability for prolonged use to the still and better insulation; sawdust and felt were used between the retaining wall and base to resist heat transfer from system to surrounding vice-versa (Figure 3).
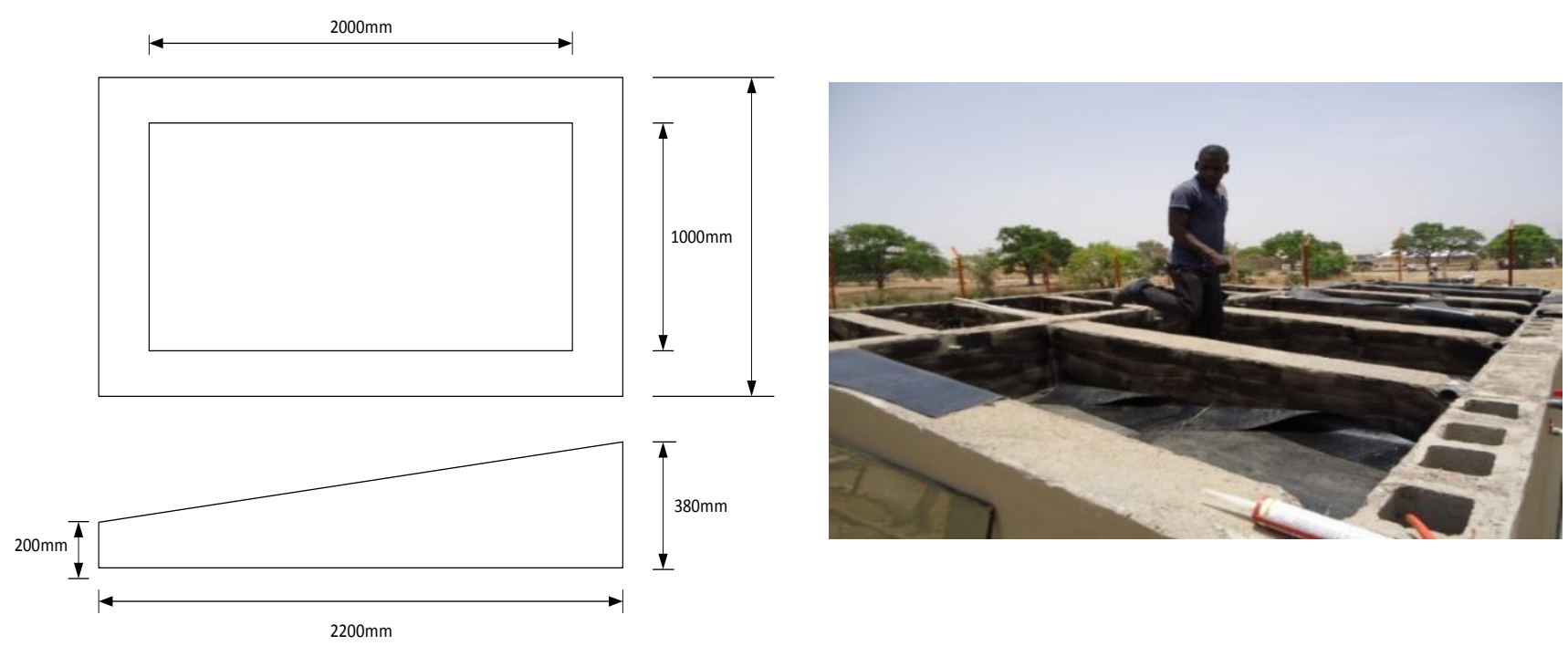

Figure 3 - Design of Retaining wall and pictorial views of the side wall 
Design and Construction of Glass pane (Top Cover) consideration. The top cover is the transparent glass pane that allows the transmission of solar radiation into the solar still. Also, it is the surface where the condensate is formed. The characteristics of a good top cover are (1) Transparent to solar radiation, (2) Non-absorbent and Nonadsorbent of water, (3) Clean and smooth surface
(4) Transmissivity (5) Durability. Glass and Polythene are the suitable materials used.

Glass ( $4 \mathrm{~mm}$ ) thick was used as a top cover and aluminium frame border to hold the glass pane firmly onto the still to avoid heat transfer and heat loss (Figure 4).

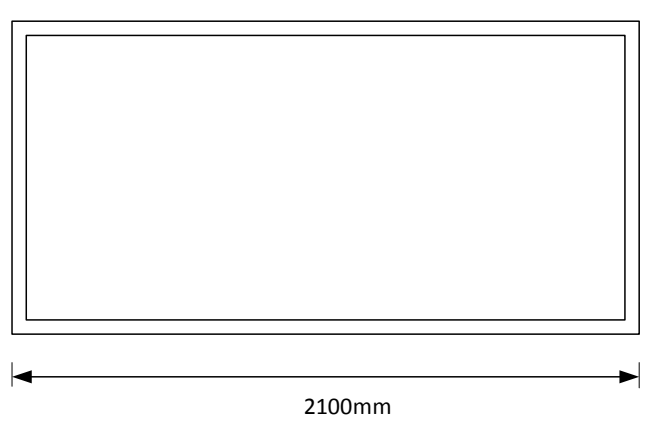

a) Design of glass frame
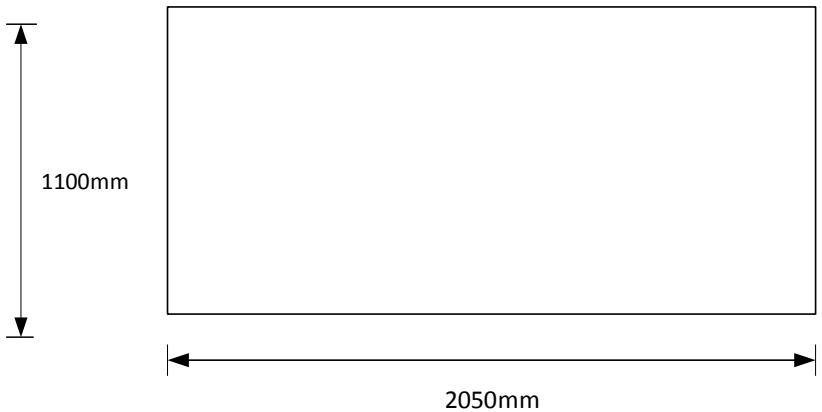

b) Transparent glass

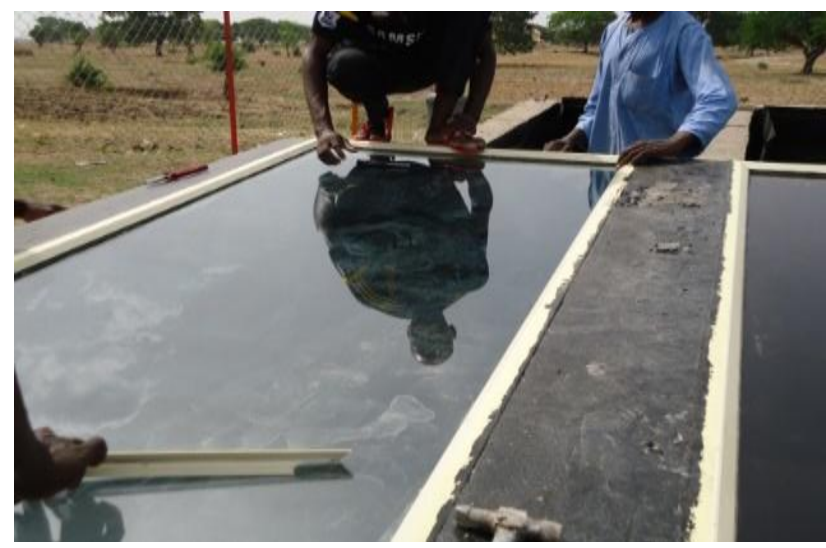

c) Pictorial view of the top cover

Figure 4 - Design of glass frame, transparent glass and pictorial view of the top cover

Design of Catch Basin/Channel consideration. The channel or catch basin this is where the condensate is collected from the inclined transparent glass top cover. The materials that can be used

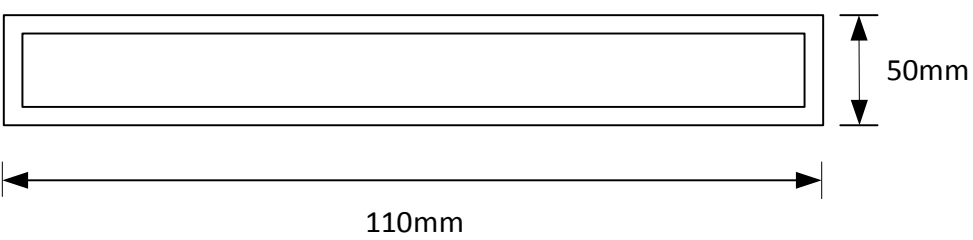

are P.V.C., G. I., and RPF. P.V.C pipe channel (size: $50 \mathrm{~mm}$ ) was used for the design (Figure 5).

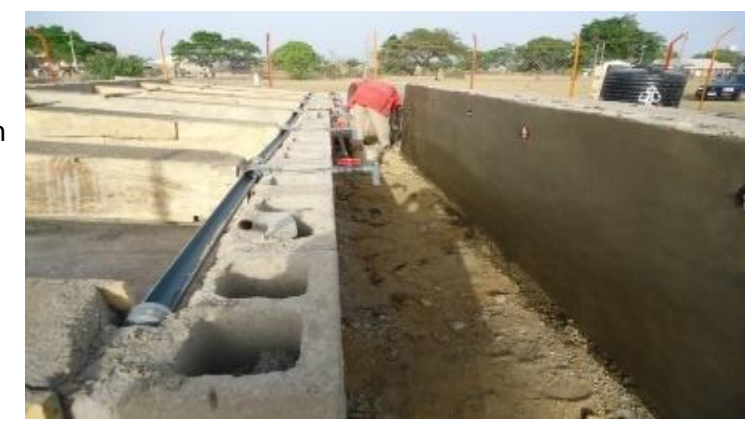

Figure 5 - Channel/Catch basin and pictorial view of the catch basin 


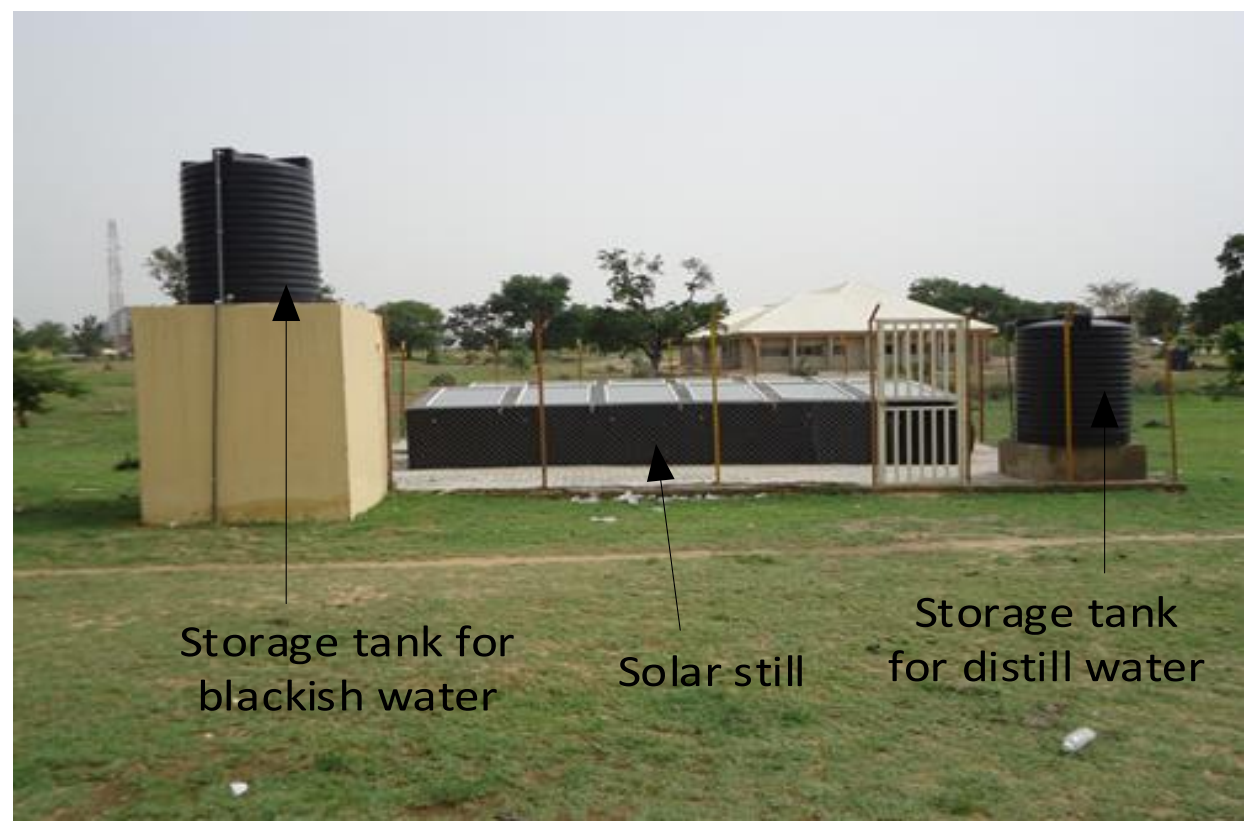

Figure 6 - Pictorial view of the constructed solar still

\section{RESULTS AND DISCUSSION}

The experiment was conducted from $14 / 02 / 2018$ to $16 / 04 / 2018$. Readings were taken from 8.00 am to 6.00 pm daily at an interval of an hour. The water depth was set at 20, 40 and $60 \mathrm{~mm}$ for the still and the inclination angle of $10.4^{\circ}$ and orientation north to south. The following readings were taken; Solar radiation, Relative Humidity, Wind velocity, Ambient temperature, Glass temperature, Air-gap temperature, Water (inside the still) temperature and $\mathrm{Ab}$ sorber plate temperature. Readings were taken using the following equipment; solar-meter, Hygrometer, Digital wind vane, Ambient temperature, an Intelligent digital multimeter with a thermocouple (Table 1-3).

Tables 1-3 above depict ambient and still conditions at 20, 40 and $60 \mathrm{~mm}$ water depth respectively. Ambient conditions are as follows; relative humidity, wind speed, and ambient temperature.

Still conditions include the following; glass, airgap, water and absorber plate temperatures respectively.

Table 1 - Ambient and still conditions at Water Depth of $20 \mathrm{~mm}$

\begin{tabular}{|l|r|r|r|r|r|r|r|r|}
\hline Time $\mathrm{hr}$ & $\begin{array}{c}\text { Humidity, } \\
\%\end{array}$ & $\begin{array}{c}\text { Solar } \\
\text { radiation, } \\
\mathrm{W} / \mathrm{m}^{2}\end{array}$ & $\begin{array}{c}\text { Wind } \\
\text { velocity, } \\
\mathrm{m} / \mathrm{s}\end{array}$ & $\begin{array}{c}\text { Ambient } \\
\text { temp., }\end{array}$ & $\begin{array}{c}\text { Air gap } \\
\text { temp., }{ }^{\circ} \mathrm{C}\end{array}$ & $\begin{array}{c}\text { Absorber } \\
\text { temp., }\end{array}$ & $\begin{array}{c}\text { Glass } \\
\text { temp., }\end{array}$ & $\begin{array}{c}\text { Water } \\
\text { temp., }\end{array}$ \\
\hline $8.00 \mathrm{am}$ & 39 & 894 & 2.80 & 32 & 40 & 40 & 36 & 38 \\
\hline $9.00 \mathrm{am}$ & 29 & 1013 & 2.09 & 34 & 45 & 45 & 42 & 43 \\
\hline $10.00 \mathrm{am}$ & 26 & 1020 & 2.34 & 36 & 52 & 52 & 45 & 54 \\
\hline $11.00 \mathrm{am}$ & 29 & 1071 & 2.87 & 36 & 51 & 51 & 49 & 53 \\
\hline $12.00 \mathrm{am}$ & 28 & 1076 & 1.42 & 37 & 57 & 57 & 53 & 60 \\
\hline $1.00 \mathrm{pm}$ & 28 & 1082 & 1.27 & 38 & 60 & 59 & 57 & 62 \\
\hline $2.00 \mathrm{pm}$ & 24 & 980 & 2.60 & 39 & 63 & 63 & 60 & 66 \\
\hline $3.00 \mathrm{pm}$ & 27 & 922 & 2.02 & 39 & 62 & 62 & 59 & 64 \\
\hline $4.00 \mathrm{pm}$ & 30 & 862 & 4.16 & 38 & 56 & 56 & 52 & 58 \\
\hline $5.00 \mathrm{pm}$ & 31 & 150 & 0.22 & 35 & 50 & 50 & 48 & 52 \\
\hline $6.00 \mathrm{pm}$ & 34 & 53 & 1.20 & 32 & 46 & 46 & 43 & 50 \\
\hline
\end{tabular}


Table 2 - Ambient and still conditions at Water Depth of $40 \mathrm{~mm}$

\begin{tabular}{|l|r|r|r|r|r|r|r|r|}
\hline Time hr & $\begin{array}{c}\text { Humidity, } \\
\%\end{array}$ & $\begin{array}{c}\text { Solar } \\
\text { radiation, } \\
\mathrm{W} / \mathrm{m}^{2}\end{array}$ & $\begin{array}{c}\text { Wind } \\
\text { velocity, } \\
\mathrm{m} / \mathrm{s}\end{array}$ & $\begin{array}{c}\text { Ambient } \\
\text { temp., }\end{array}$ & $\begin{array}{c}\text { Air gap } \\
\text { temp., }{ }^{\circ} \mathrm{C}\end{array}$ & $\begin{array}{c}\text { Absorber } \\
\text { temp., }\end{array}$ & $\begin{array}{c}\text { Glass } \\
\text { temp., }\end{array}$ & $\begin{array}{c}\text { Water } \\
\text { temp., }\end{array}$ \\
\hline $8.00 \mathrm{am}$ & 53 & 149 & 1.74 & 30 & 34 & 34 & 32 & 35 \\
\hline $9.00 \mathrm{am}$ & 46 & 653 & 1.67 & 34 & 41 & 42 & 38 & 42 \\
\hline $10.00 \mathrm{am}$ & 39 & 810 & 1.55 & 35 & 45 & 45 & 43 & 45 \\
\hline $11.00 \mathrm{am}$ & 29 & 963 & 3.25 & 36 & 52 & 52 & 49 & 54 \\
\hline $12.00 \mathrm{am}$ & 26 & 1051 & 2.35 & 38 & 55 & 54 & 53 & 59 \\
\hline $1.00 \mathrm{pm}$ & 29 & 1051 & 3.83 & 37 & 59 & 59 & 56 & 62 \\
\hline $2.00 \mathrm{pm}$ & 27 & 1160 & 3.76 & 39 & 64 & 63 & 61 & 66 \\
\hline $3.00 \mathrm{pm}$ & 28 & 1057 & 4.03 & 37 & 62 & 61 & 60 & 64 \\
\hline $4.00 \mathrm{pm}$ & 28 & 543 & 3.04 & 36 & 58 & 58 & 54 & 61 \\
\hline $5.00 \mathrm{pm}$ & 30 & 347 & 2.88 & 36 & 55 & 56 & 50 & 59 \\
\hline $6.00 \mathrm{pm}$ & 31 & 47 & 3.78 & 35 & 50 & 50 & 46 & 53 \\
\hline
\end{tabular}

Table 3 - Ambient and Still conditions at Water Depth of $60 \mathrm{~mm}$

\begin{tabular}{|l|r|r|r|r|r|r|r|r|}
\hline Time hr & $\begin{array}{c}\text { Humidity, } \\
\%\end{array}$ & $\begin{array}{c}\text { Solar } \\
\text { radiation, } \\
\mathrm{W} / \mathrm{m}^{2}\end{array}$ & $\begin{array}{c}\text { Wind } \\
\text { velocity, } \\
\mathrm{m} / \mathrm{s}\end{array}$ & $\begin{array}{c}\text { Ambient } \\
\text { temp., }\end{array}$ & $\begin{array}{c}\text { Air gap } \mathrm{C} \\
\text { temp., }{ }^{\circ} \mathrm{C}\end{array}$ & $\begin{array}{c}\text { Absorber } \\
\text { temp., }\end{array}$ & $\begin{array}{c}\text { Glass } \\
\text { temp., }{ }^{\circ} \mathrm{C}\end{array}$ & $\begin{array}{c}\text { Water } \\
\text { temp., }\end{array}$ \\
\hline $8.00 \mathrm{am}$ & 44 & 650 & 2.52 & 30 & 38 & 38 & 32 & 34 \\
\hline $9.00 \mathrm{am}$ & 24 & 1080 & 3.05 & 31 & 40 & 40 & 34 & 36 \\
\hline $10.00 \mathrm{am}$ & 19 & 1464 & 4.72 & 34 & 44 & 43 & 38 & 38 \\
\hline $11.00 \mathrm{am}$ & 17 & 1482 & 3.60 & 36 & 48 & 48 & 44 & 50 \\
\hline $12.00 \mathrm{am}$ & 13 & 1500 & 3.02 & 38 & 52 & 52 & 50 & 54 \\
\hline $1.00 \mathrm{pm}$ & 11 & 1520 & 2.85 & 40 & 56 & 56 & 53 & 59 \\
\hline $2.00 \mathrm{pm}$ & 16 & 1300 & 3.08 & 41 & 61 & 61 & 59 & 64 \\
\hline $3.00 \mathrm{pm}$ & 25 & 1100 & 2.96 & 38 & 58 & 58 & 54 & 62 \\
\hline $4.00 \mathrm{pm}$ & 29 & 845 & 3.43 & 37 & 56 & 56 & 53 & 58 \\
\hline $5.00 \mathrm{pm}$ & 45 & 635 & 3.91 & 36 & 53 & 53 & 50 & 55 \\
\hline $6.00 \mathrm{pm}$ & 51 & 124 & 2.81 & 34 & 50 & 50 & 47 & 53 \\
\hline
\end{tabular}

The tables after observation show that solar radiation increases with time from sunrise around $8 \mathrm{am}$ to $2 \mathrm{pm}$ and start decreasing from $3 \mathrm{pm}$ to sunset. Consequently, the yield and the performance of still increases with the increase of the solar radiation. The relative humidity decreases with time from 8 am to $2 \mathrm{pm}$ and increases from $3 \mathrm{pm}$ to $6 \mathrm{pm}$. However, the relative humidity reduces the performance and the yield of the solar still. The ambient temperature is less than the temperature of the still. The absorber plate record high temperature and subsequently, the temperature in still decreases in descending order; water, air-gap and glass temperatures respectively.

The higher temperature of the absorber plate indicates that it directly absorbs the solar radiation as a form of heat energy. The heat energy is transfer to the water. A change of state takes place from liquid to vapour as the water evaporates within the air-gap, as such the temperature of the air-gap is increased. As vapour makes contact with glass cover, it condenses due to decrease in temperature difference. Condensations take place because the temperature of the air-gap is greater than the glass temperature and the ambient is lower than the glass temperature.

The performance of a still can be evaluated by determining the daily yield of a still and the overnight yield, which sum is the overall or total yield of the still. The total yield is the experimental yield and is compared with the theoretical yield to the determined the efficiency of the still.

Table 4 below depict the average hourly distillate yield. It's obvious that the yield of a still is affected by the water depth. The lower the water depth, the higher the yield, $20 \mathrm{~mm}$ water depth yield distillate of $\left(5127 \mathrm{ml} / \mathrm{m}^{2} / \mathrm{hr}\right)$ and the higher the water depth, the lower the yield, $60 \mathrm{~mm}$ water depth yield distillate of (3852 ml/m²/hr). 
Table 4 - Average Overall Hourly Distillate Yield

\begin{tabular}{|l|r|r|r|r|r|r|r|}
\hline S/N & $\begin{array}{c}\text { Time } \\
\text { (hr) }\end{array}$ & $\begin{array}{c}\text { Solar } \\
\text { radiation, } \\
\text { W/m2 }\end{array}$ & $\begin{array}{c}\text { Yield } \\
(\mathrm{ml} / \mathrm{m} 2 / \mathrm{hr}), 20 \\
\mathrm{~mm} \text { depth }\end{array}$ & $\begin{array}{c}\text { Solar } \\
\text { radiation, } \\
\mathrm{w} / \mathrm{m} 2\end{array}$ & $\begin{array}{c}\text { Yield }\left(\mathrm{ml} / \mathrm{m}^{2} / \mathrm{hr}\right), \\
40 \mathrm{~mm} \text { depth }\end{array}$ & $\begin{array}{c}\text { Solar } \\
\text { radiation, } \\
\mathrm{w} / \mathrm{m} 2\end{array}$ & $\begin{array}{c}\text { Yield }\left(\mathrm{ml} / \mathrm{m}^{2} / \mathrm{hr}\right), \\
60 \mathrm{~mm} \text { depth }\end{array}$ \\
\hline 1 & $8-9$ & 894 & 15 & 149 & 8 & 650 & 4 \\
\hline 2 & $9-10$ & 1013 & 22 & 653 & 20 & 1080 & 17 \\
\hline 3 & $10-11$ & 1020 & 88 & 810 & 174 & 1482 & 65 \\
\hline 4 & $11-12$ & 1071 & 190 & 963 & 264 & 1500 & 143 \\
\hline 5 & $12-13$ & 1076 & 362 & 1051 & 389 & 1520 & 198 \\
\hline 6 & $13-14$ & 1082 & 430 & 1051 & 473 & 1300 & 297 \\
\hline 7 & $14-15$ & 980 & 560 & 1160 & 589 & 1100 & 396 \\
\hline 8 & $15-16$ & 922 & 612 & 1057 & 603 & 845 & 476 \\
\hline 9 & $16-17$ & 862 & 654 & 543 & 620 & 635 & 521 \\
\hline 10 & $17-18$ & 150 & 680 & 347 & 625 & 124 & 512 \\
\hline 11 & $18-19$ & 53 & 701 & 47 & 723 & 0 & 522 \\
\hline 12 & $19-7$ & 0 & 813 & 0 & & 701 \\
\hline
\end{tabular}

The efficiency of the still is also affected by water depth, $20 \mathrm{~mm}$ water depth, the efficiency of $51.27 \%, 40 \mathrm{~mm}$ water depth efficiency of $45.58 \%$ and $60 \mathrm{~mm}$ water depth efficiency of $38.52 \%$. The efficiency is used to evaluate the performance of the still.

Table 5 below shows the water analysis before and after distillation for both samples A and B.
The presence of bacteria in water analysis of the source water from the stream before distillation in both samples A and B and absent of bacterial in water analysis of water samples A and B after distillation ascertain the performance of the still. The water is certified safe and portable for drinking as all necessary parameters analysed are within the acceptable limit.

Table 5 - Water quality analysis before and after distillation

\begin{tabular}{|c|c|c|c|c|}
\hline \multirow{2}{*}{ Parameter } & \multicolumn{2}{|c|}{ Before distillation } & \multicolumn{2}{|c|}{ After distillation } \\
\hline & Sample A & Sample B & Sample A & Sample B \\
\hline $\mathrm{PH}$ & 8.2 & 8.2 & 7.6 & 7.6 \\
\hline Turbidity NTU & 22 & 25 & 1 & 1 \\
\hline Elect. conductivity & 190 & 210 & 20 & 22 \\
\hline TDS (mg/L) & 100 & 120 & 10 & 10 \\
\hline Total Hardness & 42 & 43 & 10 & 10 \\
\hline Total alkalinity & 135 & 128 & 1.61 & 1.60 \\
\hline Total Residual Chlorine & 2.5 & 2.4 & 0.00 & 0.00 \\
\hline Total coli form (CFU/100 L) & 100 & 104 & 0 & 0 \\
\hline Faecal coli form & 150 & 143 & 0 & 0 \\
\hline E. coli & 120 & 124 & 0 & 0 \\
\hline
\end{tabular}

The efficiency of a still can be calculated by the following equation [4]:

$$
\text { Efficiency }=\frac{\text { Experimental Yield }}{\text { Theoretical Yield }} \times 100 \text {. }
$$

$\eta=\frac{5127}{10000} \times 100 \%=51.27 \%(20 \mathrm{~mm}$ depth $)$

$$
\begin{aligned}
& \eta=\frac{4558}{10000} \times 100 \%=45.58 \%(40 \mathrm{~mm} \text { depth }) \\
& \eta=\frac{3852}{10000} \times 100 \%=38.52 \%(60 \mathrm{~mm} \text { depth })
\end{aligned}
$$

\section{CONCLUSION}

Design considerations were used in the selection of suitable material for the construction of the solar still. The plant consists of twelve still ar- 
range in two rows of six, with an area of $2 \mathrm{~m}^{2}$ for each still attached. The over-head storage tank of 2000 litres capacity for supplying brackish water (contaminated water from the stream), to the still through an input device located at the rear side of each still. And 500 litre of a storage tank for collecting distilled water via the catch basin channel and with an output device for flushing out dirty water out of the still after prolong used located at the front side of each still. Ambient and operating conditions of the plant are assumed the same for the twelve still. Overall yield (sum of daily yield and over-night yield), the efficiency of the system at a different depth $(20,40,60 \mathrm{~mm})$ $51.27 \%, 45.58 \%$ and $38.52 \%$ and water analysis before and after distillation, were all used to evaluate the performance of the solar still. Ambient and operating conditions of the still was assumed to be the same, this translates that the efficiency and total production of distillate water to be 61.55 litre at $20 \mathrm{~mm}$ water depth, 54.72 litre at $40 \mathrm{~mm}$ water depth and 46.24 litres at $60 \mathrm{~mm}$.

\section{ACKNOWLEDGEMENT}

We will like to sincerely acknowledge and appreciate Abubakar Tatari Ali Polytechnic, Bauchi for providing the fund for the research through the intervention of Institutional Based Research (IBR) of Tertiary Education Trust Fund (TETFUND) of Federal Government of Nigeria.

\section{REFERENCES}

1. Abujazar, M. S. S., Fatihah, S., Rakmi, A. R., \& Shahrom, M. Z. (2016). The effects of design parameters on productivity performance of a solar still for seawater desalination: A review. Desalination, 385, 178-193. doi: 10.1016/j.desal.2016.02.025

2. Ali Samee, M., Mirza, U. K., Majeed, T., \& Ahmad, N. (2007). Design and performance of a simple single basin solar still. Renewable and Sustainable Energy Reviews, 11(3), 543-549. doi: 10.1016/j.rser.2005.03.003

3. Atilhan, S., Linke, P., Wahab, A. A., \& Halwagi, M. M. E. (2011). A systems integration approach to the design of regional water desalination and supply networks. International Journal of Process Systems Engineering, 1(2), 125. doi: 10.1504/ijpse.2011.038941

4. Buros, O. K., \& International Desalination Association. (1990). The desalting ABCs. Topsfield: International Desalination Association.

5. Buros, O. K., International Desalination Association (IDA), \& Saline Water Coversion Corporation (SWCC). (2000). The ABCs of desalting. Denver: International Desalination Association.

6. Joe Patrick Gnanaraj, S., Ramachandran, S., \& David Santosh Christopher. (2017). Enhancing the design to optimize the performance of double basin solar still. Desalination, 411, 112-123. doi: 10.1016/j.desal.2017.02.011

7. Kaushal, A., \& Varun. (2010). Solar stills: A review. Renewable and Sustainable Energy Reviews, 14(1), 446-453. doi: 10.1016/j.rser.2009.05.011

8. Lal, R. K., Mishra, S., Dwivedi, J. P., \& Dwivedi, H. (2017). A Comprehensive Study of the Different Parameters of Solar Still. Materials Today: Proceedings, 4(2), 3572-3580. doi: 10.1016/j.matpr.2017.02.249

9. Malik, M. A. S., Tiwari, G. N., Kumar, A., Sodha, M. S. (1982). Solar Distillation. Oxford: Pergamon Press.

10. Mehta, A., Vyas, A., Nitin, B., \& Dharmesh, L. (2011). Design of Solar Distillation System. International of Advance Science and Technology, 29(1), 67-74.

11. Sharshir, S. W., Yang, N., Peng, G., \& Kabeel, A. E. (2016). Factors affecting solar stills productivity and improvement techniques: A detailed review. Applied Thermal Engineering, 100, 267-284. doi: 10.1016/j.applthermaleng.2015.11.041 